- M. L. Kronberg and F. H. Wilson: Secondary Recrystallization in Copper. Trans. AIME (1949) 185, p. 501; Journal of Metals (August 1949).

${ }^{10} \mathrm{~J}$. K. Stanley and R. F. Mehl: Recrystallization of Silicon Ferrite in Terms of Rate of Nucleation and Rate of Growth. Trans. AIME (1942) 150, p. 260.

${ }^{11} \mathrm{M}$. Cook and T. L. Richards: The Structural Changes in Copper Effected by Cold Rolling and Annealing. Journal Inst. Metals (1940) 66, p. 1.

${ }^{12} \mathrm{M}$. Cook and T. L. Richards: The Structural Changes Effected in 70:30 Brass Strip by Cold Rolling and Annealing. Journal Inst. Metals (1943) 69, p. 351.

${ }^{13} \mathrm{P}$. A. Beck and Hsun Hu: Recrystallization Texture and Coarsening Texture in High Purity Aluminum.
Trans. AIME (1949) 185, p. 627; Journal of Metals (September 1949).

"P. A. Beck, P. R. Sperry, and H. Hu: The Orienta. tion Dependence of the Rate of Grain Boundary Migra. tion. Journal of Applied Physics (1950) 21, p. 420.

${ }^{15}$ P. A. Beck: Theory of Annealing Textures. Trans AIME (1951) 191, p. 475; Journal of Metals (Junt 1951).

${ }^{10}$ A. P. Greenough: Grain Boundary Energies in Sil. ver. Royal Aircraft Establishment, Farnborough. Re. port No. Met. 52 (May 1950).

${ }^{17} \mathrm{D}$. Turnbull: Grain Boundary and Surface Diffusion. Seminar, Atom Movements. Trans. A.S.M. (1951) 43A, p. 129.

\title{
Technical Note Effect of Cold Work and Annealing on the Thermoelectric Power Of Molybdenum
}

\section{by J. Howard Kittel}

$\mathrm{T}$ HE properties of the metal molybdenum have been the subject of recent investigations ${ }^{1,2}$ which have included studies of the changes that occur in the metal when it is annealed after having been cold worked. Most of the data which have been reported have pertained to only one aspect of annealing, that is, the conditions under which recrystallization has been observed. The process of recovery which may precede recrystallization does not appear to have been investigated, and it is the purpose of this note to report observations on the recovery process in cold-worked molybdenum as determined by changes in the thermoelectric power which occur as the metal is annealed.

The measurements were made on commercially pure molybdenum wires which, after annealing at $1035^{\circ} \mathrm{C}$ in dried hydrogen for $1 \mathrm{hr}$, were swaged to give a series of reductions up to a maximum of 84.5 pct. The variously cold-worked wires were then annealed in dried hydrogen for periods of $16 \mathrm{hr}$ at progressively higher temperatures from $200^{\circ}$ to $1000^{\circ} \mathrm{C}$, with a final annealing treatment of $70 \mathrm{hr}$ at $1100^{\circ} \mathrm{C}$. After each annealing treatment the thermal emf's were determined against a length of original unworked material that had received the initial hydrogen annealing treatment. The difference in temperature between the hot and cold junctions was maintained at about $75^{\circ} \mathrm{C}$, and the thermal emf's were measured with a potentiometer that could be read to 0.01 microvolt.

Fig. 1 shows the thermoelectric power $(d E / d T)$ in microvolts per ${ }^{\circ} \mathrm{C}$ between annealed and coldworked molybdenum as a function of the degree of cold work. The effect of annealing is shown in Fig. 2. The general shape of the curves in both figures is similar to results which have been obtained for copper. ${ }^{8}$ It was observed that after annealing at temperatures as low as $200^{\circ} \mathrm{C}$ recovery was well under way. The rapid changes in thermoelectric power observed near $900^{\circ} \mathrm{C}$ are probably associated with recrystallization, since such a relation has been observed with copper..$^{3}$ Beyond $900^{\circ} \mathrm{C}$ the thermal emf's changed in polarity, indicating that from this point on the specimens were more highly annealed

J. HOWARD KITTEL, formerly with NACA Lewis Flight Propulsion Laboratory, Cleveland, is now with Argonne National Laboratory, Chicago.

TN 92E. Manuscript, Sept. 13, 1951.

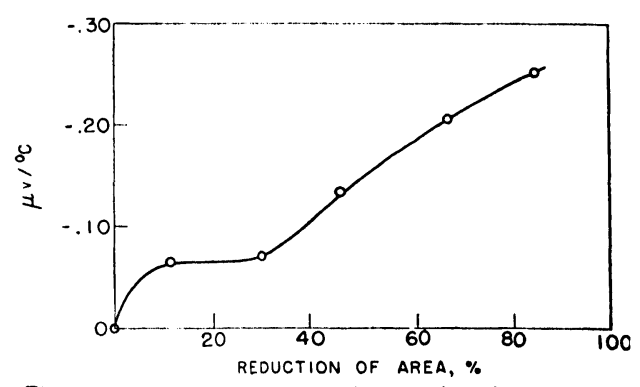

Fig. 1-Effect of cold work on the thermoelectric power of molybdenum.

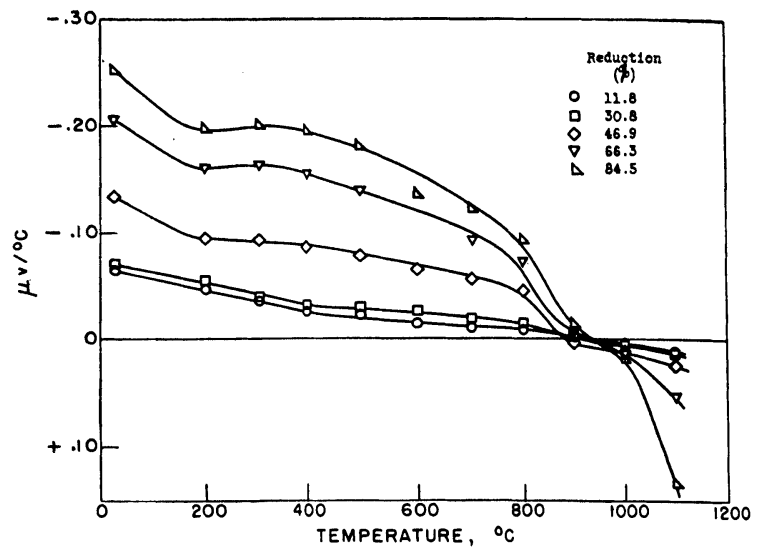

Fig. 2-Effect of annealing on the thermoelectric power of cold-worked molybdenum.

than the standard. Annealing treatments could not be given at temperatures higher than $1100^{\circ} \mathrm{C}$ due to limitations of the furnace, and it is evident that, since equilibrium values of thermoelectric powers were far from having been attained, temperatures considerably higher are required to fully anneal molybdenum.

\section{References}

${ }^{1}$ Robert M. Parke: Molybdenum, A New High-Temperature Material. Metal Progress (1951) 60, pp. 81-96.

${ }^{2}$ R. A. Long, K. C. Dike, and H. R. Bear: Some Properties of High-Purity Sintered Wrought Molybdenum Metal at Temperatures up to $2400^{\circ} \mathrm{F}$. NACA TN 2319 (March 1951).

${ }^{3}$ G. W. Brindley: A Thermo-Electric Study of the Cold-Rolling and Heat-Treatment of Copper. Report of a Conference on the Strength of Solids. Physical Society, London (1948) pp. 95-106. 